\title{
Crepuscular activity of culicids (Diptera, Culicidae) in the peridomicile and in the remaining riparian forest in Tibagi river, State of Paraná, Brazil
}

\author{
Gerson A. Müller ${ }^{1}$, Ana C. Dalla Bona1 ${ }^{1}$ Carlos B. Marcondes² \& Mário A. Navarro-Silva ${ }^{1,3}$
}

${ }^{1}$ Laboratório de Entomologia Médica e Veterinária do Departamento de Zoologia, Setor de Ciências Biológicas da Universidade Federal do Paraná. Caixa Postal 19020,81531-980 Curitiba-PR, Brasil.gecoazul@hotmail.com; ana.dalla@ig.com.br

${ }^{2}$ Departamento de Microbiologia e Parasitologia, Centro de Ciências Biológicas, Universidade Federal de Santa Catarina, 88040-900 Florianópolis-SC, Brasil.cbrisola@mbox1.ufsc.br

${ }^{3}$ Corresponding author. mnavarro@ufpr.br

\begin{abstract}
Crepuscular activity of culicids (Diptera, Culicidae) in the peridomicile and in the remaining riparian forest in Tibagi river, State of Paraná, Brazil. Human-attracted mosquitoes were collected for one hour, around sunset time (half hour before and half after), from April to December 2006, in two environments (riparian forest and near houses), in Tibagi river basin, Palmeira municipality, State of Paraná. Seven-hundred forty-nine mosquitoes, belonging to 13 species, were collected. Psorophora champerico Dyar \& Knab, 1906 (42.86\%) and Psorophora discrucians (Walker, 1856) (40.59\%) were the most frequent species. No significant differences between quantities of Ps. champerico $(\mathrm{t}=-0.792$; d.f. $=16 ; \mathrm{p}=0.43)$ and Ps. discrucians $(\mathrm{t}=0.689$; d.f. $=16 ; \mathrm{p}=0.49)$ obtained in riparian forest and near houses were observed, indicating similar conditions for crepuscular activity of these species in both environments. Psorophora champerico and Ps. discrucians responded (haematophagic activity) to environmental stimuli associated with the twilight hours differently in distinct habitats studied. The former species is registered for the first time in the Atlantic forest biome.
\end{abstract}

KEYWORDS. Crepuscular activity; mosquitoes; Psorophora discrucians; Psorophora champerico.

RESUMO. Atividade crepuscular de culicídeos (Diptera, Culicidae) no peridomicílio e remanescentes de matas ciliares do Rio Tibagi. Estado do Paraná, Brasil. Mosquitos atraídos por humanos foram coletados por uma hora em torno do crepúsculo vespertino (meia hora antes e meia hora depois), de abril a dezembro de 2006, em dois locais (mata ciliar e peridomicílio) na bacia do Rio Tibagi, município de Palmeira, Estado do Paraná. Foram capturados 749 mosquitos distribuídos em 13 espécies. Psorophora champerico Dyar \& Knab, 1906 (42,86\%) e Ps. discrucians (Walker, 1856) (40,59\%) foram as espécies mais freqüentes. Não foram registradas diferenças significativas entre as médias de indivíduos capturados entre os pontos de mata ciliar e peridomicílio para Ps. champerico $(\mathrm{t}=-0,792 ; \mathrm{g} .1 .=16 ; \mathrm{p}=0,43)$ e para Ps. discrucians $(\mathrm{t}=0,689 ; \mathrm{g} .1 \mathrm{l}=16 ; \mathrm{p}=0,49)$. Isto demonstra que os dois ambientes estudados fornecem condições semelhantes para a atividade crepuscular destas espécies. Psorophora champerico e Ps. discrucians responderam (atividade hematofágica) aos estímulos ambientais associados ao horário crepuscular de forma distinta nos diferentes habitats analisados. Foi registrada pela primeira vez a presença de Psorophora champerico no bioma Mata Atlântica.

PALAVRAS-CHAVE. Atividade crepuscular; mosquitos; Psorophora discrucians; Psorophora champerico.

Because of transmission of several pathogens and disturbance caused by bites, studies on the ecology of mosquitoes are very important for public health. In South region of Brazil, urbanization and exploitation of environment have caused several modifications in areas originally covered by forest. After these modifications, some species, such as Ochlerotatus scapularis (Rondani, 1848) e Psorophora ferox (Humboldt, 1819 ) could proliferate, becoming pests, sometimes transmitting viruses and parasites (Forattini et al. 1981; Walsh et al. 1993; Marchi et al. 2010).

In Paraná state, most studies have been developed in eastern region, because of the presence of extensive forested areas (e.g. Sant'Ana \& Lozovei 2001; Silva et al. 2004; Bona $\&$ Navarro-Silva 2008). In the western region of the state, forests have been reduced to small fragments near rivers and creeks because of the land use mainly for agriculture. Although the mosquito fauna around Londrina municipality was studied (e.g. Lopes et al. 1993, 2002), mosquito species distribution in that area is still poorly known.
The existence of forest fragments near rivers allows contact between mosquitoes and human populations, the former sometimes biting near domiciles. The present work aims to study the crepuscular biting activity of mosquitoes in two areas, one in peridomicile and other inside a riparian forest, near the Tibagi River, in the midwest region of the State of Paraná

\section{MATERIAL AND METHODS}

The study area is situated in Atlantic Forest biome, and its climate is subtropical humid, with no dry season; mean annual temperature is $18^{\circ} \mathrm{C}$ and rainfall is $1,550 \mathrm{~mm}$ (Mendonça 2000). Collections were carried out in a locality situated near Tibagi river, at Palmeira municipality, Paraná state (25'23'16"S, 4958'58'W, $820 \mathrm{~m}$ altitude). There are two houses in the location, one is always occupied by three inhabitants, and the other occasionally by eight. At one side of houses, at $300 \mathrm{~m}$, there is an area, utilized for sugar cane 
and corn plantations, and on the other side, at $30 \mathrm{~m}$, riparian vegetation around Tibagi River.

Two collection sites, separated by $800 \mathrm{~m}$, were selected: (1) near both houses, in the peridomicile, and (2) in a riparian forest, on river margin. The riparian forest was $20 \mathrm{~m}$ wide, and it contains bushes and trees, varying from dense to more open distributed, with some ground depressions that accumulate water from both rain and river flooding.

Nine field collections were carried out from April to December 2006. Collections started 30 minutes before sunset (periods 1 and 2) and lasted for 30 minutes after sunset (periods 3 and 4). The local starting time fluctuated according to sunset hour, previously informed by Instituto Agronômico do Paraná (IAPAR), from 05:09 to 06:30 p.m., and ended from 06:09 to 07:30 p.m. Collectors arrived 30 minutes before starting collections in order to prevent "intrusion effect" (Forattini et al. 1981).

Two collectors worked in each point, one attracting mosquitoes and the other collecting them, utilizing a battery-fed suction device, before mosquito could bite the person. Collector vials were replaced every 15 minutes. Mosquitoes were deposited in Coleção Entomológica Pe. J. S. Moure, in Departamento de Zoologia, Universidade Federal do Paraná, Curitiba, Paraná.

Williams means $\left(\mathrm{X}_{\mathrm{w}}\right)$ multiplied by 100 (Forattini et al. 1981) were estimated for the most frequent species. Comparisons between means of these species and between collection points were made by t test, using Statistic 7.0 software (StatSoft). Data were normalized by formula $\mathrm{Y}^{\prime}=(\mathrm{Y}+0.5)^{1 / 2}$, and were validated by Shapiro-Wilk test of normality.

Adult mosquitoes were identified using descriptions and identification keys by Dyar \& Knab (1906), Lane (1953),
Consoli \& Lourenço-de-Oliveira (1994) and Forattini (2002). Genera and subgenera of Culicidae were abbreviated according to Reinert (1975) and Ochlerotatus was considered as a genus (Reinert 2000).

\section{RESULTS AND DISCUSSION}

Seven-hundred forty-nine mosquitoes of eight genera and 13 species were collected (Table I). Psorophora was the most abundant (84.25\%) and, also the most diversified genus, with four species. Psorophora includes several aggressive and anthropophilic species, is active during crepuscular period, proliferates in sylvatic degraded environments, and their immature forms are associated to temporary larval habitats (Teodoro et al. 1994; Forattini 2002; Oscherov et al. 2007).

Psorophora champerico $(42.86 \%)$ e Ps. discrucians $(40.59 \%)$ were the most abundant species in collections. The last one had been collected during vespertine crepuscule in residual forests and modified vegetation, in several states of Brazil (Forattini et al. 1968; Consolim et al. 1993; Natal et al. 1998; Marcondes et al. 2006). Distribution of Ps. champerico includes Central America, northern part of South America and Amazon region (Lane 1992; Reinert et al. 2005). This is the first report of the species in Atlantic forest, near the southern limit of the bioma, indicating underestimation of its distribution (Tabarelli et al. 2005).

The amount of specimens of both species varied among collections with high standard deviations (Ps. champerico: $7.56 \pm 10.49$ in riparian forest and $12.50 \pm 22.62$ in peridomicile; Ps. discrucians: $9.60 \pm 23.54$ and $5.60 \pm 10.97$ respectively). Variation was probably caused by seasonal fluctuation in temperatures and rain and to transitory nature of

Table. I. Culicidae collected in riparian forest and peridomicile areas in Palmeira municipality, State of Paraná, Brazil, from April to December of 2006.

\begin{tabular}{|c|c|c|c|c|}
\hline Species & Peridomicile & Riparian forest & Total & $\%$ \\
\hline \multicolumn{5}{|l|}{ Anophelinae } \\
\hline Anopheles strodei Root, 1926 & 11 & 13 & 24 & 3.20 \\
\hline \multicolumn{5}{|l|}{ Culicinae: Aedini } \\
\hline Ochlerotatus pennai (Antunes \& Lane, 1938) & 1 & - & 1 & 0.13 \\
\hline Ochlerotatus scapularis (Rondani, 1848) & 6 & 10 & 16 & 2.14 \\
\hline Ochlerotatus serratus (Theobald, 1901) & 23 & 33 & 56 & 7.48 \\
\hline Psorophora albigenu Peryassu, 1908 & - & 1 & 1 & 0.13 \\
\hline Psorophora albipes (Theobald, 1907) & 2 & 3 & 5 & 0.67 \\
\hline Psorophora champerico (Dyar \& Knab, 1906) & 200 & 121 & 321 & 42.86 \\
\hline Psorophora discrucians (Walker, 1856) & 111 & 193 & 304 & 40.59 \\
\hline \multicolumn{5}{|l|}{ Culicinae: Aedeomyiini } \\
\hline Aedeomyia squamipennis (Lynch Arribálzaga, 1878) & 1 & - & 1 & 0.13 \\
\hline \multicolumn{5}{|l|}{ Culicinae: Culicini } \\
\hline Culex vaxus Dyar, 1920 & - & 7 & 7 & 0.93 \\
\hline \multicolumn{5}{|l|}{ Culicinae: Mansoniini } \\
\hline Coquillettidia juxtamansonia (Chagas, 1907) & 1 & - & 1 & 0.13 \\
\hline \multicolumn{5}{|l|}{ Culicinae: Sabethini } \\
\hline Runchomyia reversa Lane \& Cerqueira, 1942 & 2 & 8 & 10 & 1.34 \\
\hline Trichoprosopon soaresi Lane \& Cerqueira, 1942 & - & 2 & 2 & 0.27 \\
\hline Total & 358 & 391 & 749 & 100.00 \\
\hline
\end{tabular}


larval habitats. This influence of temperature and other seasonal factors on mosquitoes was also noted by Silva \& Lozovei (1998) in a fragment of Atlantic Forest in the Paraná state.

There was no significant difference between the mean amount of mosquitoes collected between points 1 and 2 for Ps. champerico $(\mathrm{t}=-0.792 ;$ d.f. $=16 ; \mathrm{p}=0.43)$ and $P S$. discrucians $(\mathrm{t}=0.689$; d.f. $=16 ; \mathrm{p}=0.49)$. This shows that, even having potential larval habitats only in the riparian forest, both environments provided similar conditions for adults activity of both species. These results contrast with those of Guimarães et al. (1989) and Barbosa et al. (2008), which showed, also in rural areas, that species of Psorophora have a lower activity around houses, compared to forest fragments.

Biting activity of $P S$. champerico in peridomicile increased from period $1\left(\mathrm{X}_{\mathrm{w}}=43.7\right)$ to period $4\left(\mathrm{X}_{\mathrm{w}}=142.2\right)$, while in riparian forest, Williams means were respectively 96.8 and 57.6 (Fig. 1). The biting activity of Ps. discrucians also increased from period $1\left(\mathrm{X}_{\mathrm{w}}=51.4\right)$ to period $4\left(\mathrm{X}_{\mathrm{w}}=\right.$ $61.6)$ in peridomicile, and in riparian forest $X_{w}$ were respectively 65.3 and 42.1 (Fig. 2). Propensity of Psorophora mosquitos to bite preferably in peridomicile in the end of crepuscular period can have epidemiological implications and should be more extensively studied. Gomes et al. (2010) also observed influence of environment on activity peak of mosquitoes.
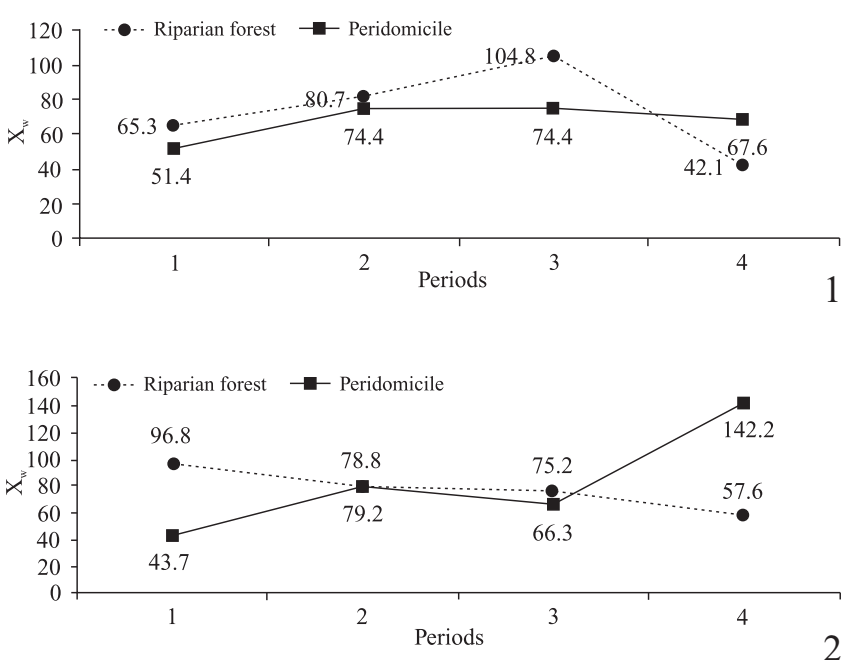

Figs. 1-2. Williams's means $\left(\mathrm{X}_{\mathrm{w}}\right)$ of Psorophora champerico (1) and Psorophora discrucians (2) collected in vespertine crepuscular period, separated in 15-minutes periods $(1,2,3$ and 4$)$ in riparian forest and peridomicile at Palmeira municipality, state of Paraná, Brazil, from April to December 2006.

Thus, the dominance of species of Psorophora in relation to other groups of Culicidae captured in the Tibagi area, both in peridomicile and in the riparian forest, indicates a possible epidemiological importance of these mosquitoes when they feed upon humans during the crepuscular period. This study demonstrated that species as Ps. champerico and
Ps. discrucians show biting pattern similar in peridomicile area and riparian forest, but their activity peaks during the twilight can vary depending on the habitat.

\section{ACKNOWLEDGEMENTS}

We thank CNPq for Ph. D. scholarship for ACDB and GAM. Aristides Fernandes (DE/FSP/USP), for helping in the identification of some mosquitoes. Everaldo Hass for authorizing collection in his property and to biologist Cezar Capriglioni Carvalho Junior for assistance in the field collection of mosquitoes.

\section{REFERENCES}

Barbosa, M. das G. V.; N. F. Fé; A. H. R. Marcião; A. P. T. da Silva; W. M. Monteiro; M. V. de F. Guerra. \& J. A. de O. Guerra. 2008. Registro de Culicidae de importância epidemiológica na área rural de Manaus, Amazonas. Revista da Sociedade Brasileira de Medicina Tropical 41: $658-663$.

Bona, A. C. D. \& M. A. Navarro-Silva. 2008. Diversidade de Culicidae durante os períodos crepusculares em bioma de Floresta Atlântica e paridade de Anopheles cruzii (Diptera: Culicidae). Revista Brasileira de Zoologia 25: 40-48.

Consoli, R. A. G. B. \& R. Lourenço-de-Oliveira. 1994. Principais mosquitos de importância sanitária no Brasil. Rio de Janeiro, Fiocruz, 228p.

Consolim, J.; N. J. M. Pellegrini \& E. Luz. 1993. Culicídeos (Diptera, Culicidae) do lago de Itaipú, Paraná, Brasil. Acta Biológica Paranaense 22: 83-90.

Dyar, H. G. \& F. Knab 1906. Diagnoses of new species of mosquitoes Proceedings of the Biological Society of Washington 19: 133-142.

Forattini, O. P.; O. S. Lopes \& E. X. Rabello. 1968. Investigações sôbre o comportamento de formas adultas de mosquitos silvestres no Estado de São Paulo, Brasil. Revista de Saúde Pública 2: 111-173.

Forattini, O. P.; A. de C. Gomes; J. L. F. Santos; E. A. B. Galati; E. X. Rabelo \& D. Natal. 1981. Observações sobre a atividade de mosquitos Culicidae, em mata residual no Vale da Ribeira, S. Paulo, Brasil. Revista de Saúde Pública 15: 557-586.

Forattini, O. P. 2002. Culicidologia Médica: identificação, biologia e epidemiologia. vol. 2, São Paulo, EDUSP, 864p.

Gomes, A. de C.; M. B. de Paula; D. Natal; S. L. D. Gotlieb \& L. F. Mucci. 2010. Effects of flooding of the River Paraná on the temporal activity of Anopheles (Nyssorhynchus) darlingi Root (Diptera: Culicidae), at the border State of Mato Grosso do Sul and São Paulo, Brazil. Revista da Sociedade Brasileira de Medicina Tropical 43: 516-522.

Guimarães, A. E.; M. A. Motta; M. A. R. M. Machado \& L. D. Gonçalves. 1989. Bionomia de mosquitos (Diptera: Culicidae) em áreas da Mata Atlântica no município de Itaguaí, Estado do Rio de Janeiro, Brasil. I. Freqüência intra, peri e extradomiciliar. Memórias do Instituto Oswaldo Cruz 84: 243-254.

Lane, C. J. 1953. Neotropical Culicidae. Vol. 2, São Paulo, EDUSP, 564 p.

Lane, C. J. 1992. On a collection of Culicinae (Diptera: Culicidae) from Brazil. Mosquito Systematics 24: 16-22.

Lopes, J.; M. A. N. da Silva; A. M. Borsato; V. D. R. B. de Oliveira \& F. J. de A. Oliveira. 1993. Aedes (Stegomyia) aegypti L. e a culicideofauna associada em área urbana da região sul, Brasil. Revista de Saúde Pública 27: 326-333.

Lopes, J.; J. A. C. Zequi; V. Nunes; O. de Oliveira; B. P. de O. Neto \& W. Rodriguez. 2002. Immature Culicidae (Diptera) collected from the Igapó lake located in the urban area of Londrina, Paraná, Brazil. Brazilian Archives of Biology and Technology 45: 465-471.

Marchi, M. J.; G. A. Müller \& C. B. Marcondes. 2010. Mosquitos (Diptera: Culicidae) de uma futura Unidade de Conservação em área de Mata Atlântica no Sul do Brasil. EntomoBrasilis 3: 34-37. 
Marcondes, C. B.; A. Fernandes \& G. A. Müller. 2006. Mosquitoes (Diptera: Culicidae) near a reservoir in the Western part of the Brazilian State of Santa Catarina. Biota Neotropica 6: http://www.biotaneotropica.org.br/ v6n3/pt/abstract?inventory+bn02606032006, (accessed 25th July 2011).

Mendonça, F. A. 2000. A tipologia climática: Gênese, características e tendências, p. 21-62. In: N. A. F. Stipp (ed.). Macrozoneamento ambiental da Bacia Hidrográfica do Rio Tibagi (PR). Londrina, Eduel, $196 \mathrm{p}$

Natal, D.; E. A. M. de F. Barata; P. R. Urbinatti; J. M. S. Barata \& M. B. de Paula. 1998. Sobre a fauna de mosquitos adultos (Diptera, Culicidae) em área de implantação de hidrelétrica na bacia do Rio Paraná, Brasil. Revista Brasileira de Entomologia 41: 213-216.

Oscherov, E. B.; M. E. Bar; M. P. Damborsky \& G. Avalos. 2007. Culicidae (Diptera) de La Reserva Provincial Iberá, Corrientes, Argentina. Boletín de Malariología y Salud Ambiental 47: 221-229.

Reinert, J. F. 1975. Mosquito generic and subgeneric abbreviations (Diptera: Culicidae). Mosquito Systematics 7: 105-110.

Reinert, J. F. 2000. New classification for the composite genus Aedes (Diptera: Culicidae: Aedini), elevation of subgenus Ochlerotatus to generic rank, reclassification of the other subgenera, and notes on certain subgenera and species. Journal of the American Mosquito Control Association 16: 175-188.
Reinert, J. F.; R. E. Harbach \& M. A. M. Sallum. 2005. Checklist of aedine mosquito species (Diptera, Culicidae, Aedini) occurring in Middle and South America (south of the United States) reflecting current generic and subgeneric status. Revista Brasileira de Entomologia 49: 249-252.

Sant'Ana, A. L. \& A. L. Lozovei. 2001. Influência do ciclo lunar na captura de Aedes scapularis (Diptera, Culicidae) na Mata Atlântica do Paraná. Iheringia, Série Zoologia 90: 175-182.

Silva, M. A. N. da \& A. L. Lozovei. 1998. Mosquitos (Diptera, Culicidae) capturados com isca humana em área preservada de Curitiba, Paraná. Revista Brasileira de Zoologia 15: 965-976.

Silva, A. M. da; V. Nunes \& J. Lopes. 2004. Culicídeos associados a entrenós de bambu e bromélias, com ênfase em Aedes (Stegomyia) albopictus (Diptera, Culicidae) na Mata Atlântica, Paraná, Brasil. Iheringia, Série Zoologia, 94: 63-66.

Tabarelli, M.; L. P. Pinto; J. M. C. Silva; M. M. Hirota \& L. C. Bedê. 2005. Desafios e oportunidades para a conservação da biodiversidade na Mata Atlântica brasileira. Megadiversidade 1: 132-138.

Teodoro, U.; A. L. F. Guilherme; A. L. Lozovei; V. La S. Filho; A. A. Sampaio; R. P. Spinosa; M. E. M. C. Ferreira; O. C. Barbosa \& E. M. Lima. 1994. Mosquitos de ambientes peri e extradomiciliares na região sul do Brasil. Revista de Saúde Pública 28: 107-115.

Walsh, J. F.; D. H. Molyneux \& M. H. Birley. 1993. Deforestation: effects on vector-borne disease. Parasitology 106: 55-75.

Received 8/8/2011; accepted 2/1/2012

Editor: Maria Anice Mureb Sallum 